\title{
アラミド紙を用いた電子回路基板のねじれと繊維配向
}

\author{
王子製紙侏新技術研究所 永田紳一 \\ 松下電器産業侏デバイス・エンシニアリング開発センター 川北嘉洋 \\ 山形大学工学部 小山清人
}

\section{Relationship between Fiber Orientation and Twist of Circuit Board with Aramid Fibers}

\author{
Shinichi Nagata*1, Yoshihiro Kawakita ${ }^{* 2}$, and Kiyohito Koyama ${ }^{* 3}$ \\ ${ }^{* 1}$ Advanced Technology Research Laboratory, Oji Paper Co., Ltd., 4-3-1 Jokoji, Amagasaki-shi, Hyogo, \\ 660-8577 Japan \\ ${ }^{* 2}$ Device Engineering Development Center, Matsushita Electric Industrial Co., Ltd., 1006 Kadoma, \\ Kadoma-shi, Osaka, 571-8501 Japan \\ ${ }^{* 3}$ Faculty of Engineering, Yamagata University, 4-3-16 Jonan, Yonezawa-shi, Yamagata, 992-8510 Japan
}

\begin{abstract}
The twist for circuit boards containing aramid fibers was investigated from the viewpoint of the thermal shrinkage caused by their fiber orientation. Fiber orientation was measured by microwave method, which is based on the dielectric anisotropy. It was confirmed that the fiber orientation could be estimated from the dielectric anisotropy of samples. The dielectric anisotropy measured by microwave method for uniaxially oriented glass fibers was in good agreement with the law of mixture, which shows the appearance of dielectric anisotropy caused by the shape of island (fiber) in the islands-sea structure. On the other hand, the ratio of coefficient of thermal expansion against the orientation degree by microwave method was studied by thermomechanical analysis. Calculated results by our proposed model for the twist of circuit boards were in good agreement with values measured on Japanese Industrial Standard. In order to minimize the twist of two-ply circuit board, the orientation degrees should be minimum or orientation angles of two ply should be the same.
\end{abstract}

(Received 23 April, 1998 ; Accepted 19 June, 1998)

\section{1. 緒 言}

エレクトロニクス寒装技術の高密度化，高速化に対応 してプリント回路板の材料革新が起こっている，高度表 面実装に用いる基板には，これまでにない高精度，すな わち低膨張，高純度，耐熱，耐湿，高度寸法安定性など の性能が要求される。アラミド䋐維を用いた基板もその
1つであり，低熱膨張 (負の值)，低誘電率，レーザー加 工性, 軽量といった特隻を有しており，かつ酎熱性、強 度も十分であるため，最近では㩲帯電話用基板をはじ 種々の用途に使われ出した。

積層板の基板の形態，つまり織物と紙の特質について

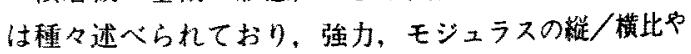
寸法安定性は多分に製法に関わるが、一般に新の方がコ 
ントロールしやすいという特徵がある(1).しかし，紙 を抄造する過程にわいて付与される戴維の配向が熱収縮 の異方性と密接に関保しているため，積層した場合にそ ク・ねしれが発生し，基板に部品を実装する際に不都合 が生しる場合がある。

維の樴維配向を測定する方法としては従来から，超音 波法[2]，力学的破断強度、水拡散法[3]などが用いら れてている。超音波法は弾性率の異方性に伴う超音波 伝稳速度の方向依存性を見ており、アラミドプリブレグ の場合は，澍脂を含浸させるために表面が硬くなり，表 面の配向状態に依存してしまい内部まで含めた全体の配 向を正確に反映しない場合がある。他の2つについては， 時間と労力がかかるという現実的な問題がある。

我々は誘電率の異方性に基づくマイク口波透過強度の 角度依存性から，紙・フィルムなとの配向を測定するマ 1ク波法 $[4,5]$ 用いて、アラミド紙の䋞維配向を測定 した。とえ载維そのものは等方性であっても，その形 態によってマク口的な誘電率の異方性が発現することを 表した式(6)がマイク口波法にも適用できることを，が ラス驖維を一軸配向させた試料を作成して確認した，ま んアラミド紙の線膨張保数比と繊維配向度との間に強 い相関関係が認められたので，マイクロ波法による䋐維 既向測定值を用いて衫じれ量を表寸式を提案した。これ による計算值とJISに基づく実際の回路基板のねじれ量と の関についても検討したのでこれらの結果について 報告する。

\section{2. 理 論}

\section{1 マイクロ波法による眍向測定原理}

图1にマイク口波空洞共振器の概略を示す。発振器か ら出たマイクロ波は空洞共振器内に導かれ、試料を透過 した後検波器で電圧信号に変換され，コントローラで増 㥜 $\mathrm{A} / \mathrm{D}$ 変換された後、コンピェータで処理される。試 料空洞共振器内で1回転し，その間のマイクロ波透過

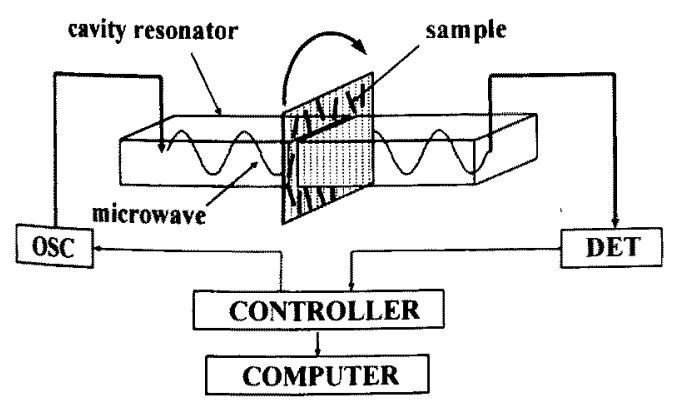

Fig. 1 Block diagram of microwave method for measuring the fiber orientation.

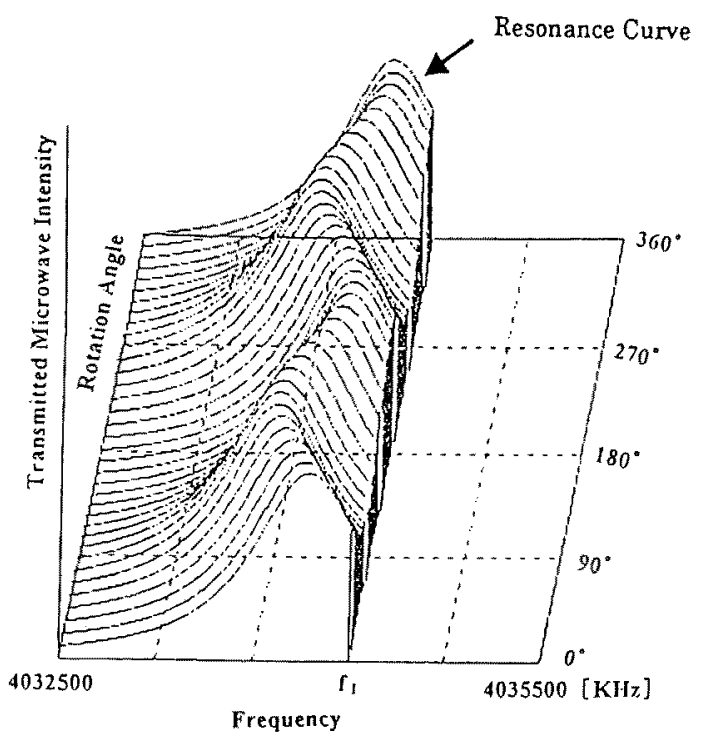

(a)

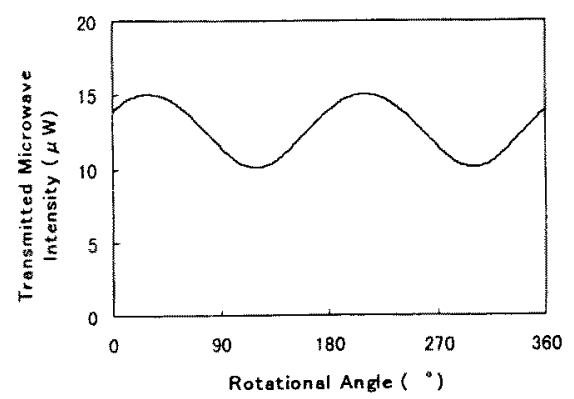

(b)

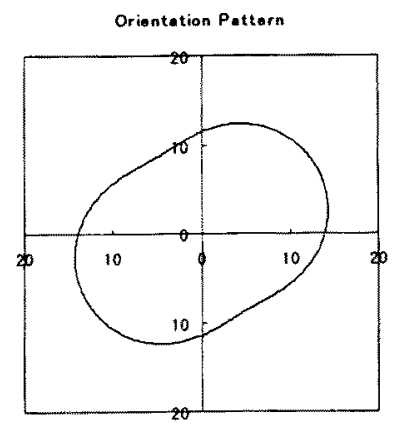

(c)

Fig. $2{ }^{\text {(a) }}$ Shift of resonance curve based on the dielectric constant.

(b) Shift of resonance curve can be detected as change of transmitted microwave intensity.

${ }^{(c)}$ Angular dependence of transmitted micro. wave intensity is shown as orientation pattern by plotting on R- $\theta$ coordinates. 
强度の回転角度依存性から，园2（c）の上う配向パタ一 ンが得られる。空洞共据器においてい，式(1)に示すよう

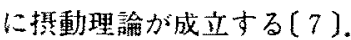

$$
\frac{\omega-\omega_{a}}{\omega_{a}} \approx \frac{1}{4 \mathrm{~W}} \int_{d v}\left[\left(\mathrm{P}+\frac{\mathrm{J}}{\mathrm{j} \omega_{a}}\right) \cdot \mathrm{E}_{a}{ }^{*}+\mu_{0} \mathrm{M} \cdot \mathrm{H}_{a}{ }^{*}\right] d \nu
$$

ただし, $\mathrm{W}=\frac{1}{2} \int_{\nu} \varepsilon\left|\mathrm{E}_{a}\right|^{2} d \nu$

$こ こ て ゙, \omega_{a}:$ ブランク時の固有角周波数, $\omega$ : 試料择入 時の固有角周波数, $\mathrm{E}_{a}$ : 電界振幅, $\mathrm{H}_{0}$ : 磁界振幅, $\mathrm{W}$ : 空洞内蓄積エネルギー, $\Delta \mathrm{V}:$ 試料の容䆊, $\mathrm{V}$ : 毕洞共振 器の容積, $\mathrm{P}$ : 固体試料の電気分極, $\mathrm{M}$ : 磁化, $\mathrm{J}$ : 導電 電流密度である。

これは曆さが均一であれば，試料の誘電染に対応して 共振周波数が低周波数側八シフトすることを意味する。 本方式では偏波を用いているた力，電界くクトルが試紏 面に平行にかつ図中での上下方向にのみ存在するので面 方向の颜電萃に依存した其振カーブが得られることにな る。舟し試料に面内誘電率の異方性があ机ば，1回転中 に共振力ーブは図 2 (a)のようにシフトする.アイクロ波 の周波数を共振カーブのピークレふルのの1/2になる高周 波側の点(图のf1)で固定して試料を1回転すれば，其振力 ーブのシフトは网 2 (b)のように透過强度の変化として とらえることができる、その結果，四2（c）のような透過 強度の角度依存性(配向パターン)が得られることになる。 もちろん，誘電損率の基方性加大きい場合は，試料の1 回転中に共振力ーブの形が変化し，その分だけ配向パ夕 ーンに嵒差となって現れる場合があるが，共振カーブの 形が変化せず,かつ共振カーブの右局(高周波側でかつピ 一タレベルの1/2付近)が直線であれぱ,配向パターンは 誘電率の異方性を忠実に反映させたものに成り得る。こ こで，配向パターンの短軸方向が誘電㳯最大の方向を示 すことになり，その楕冈の程度(長軸と短軸の比)が配向 度を示す。つまり無配向では周波数シフトが無いため， 配向パターンは円になり，配向度が增すにつれて棈円が くびれてくる。たとえば图3のように赫維の配向状態に

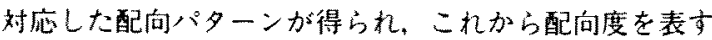
MOR (Microwave Orientation Ratio) が長軸/短軸とし て計算される、なお，配向パ多ーンは同一の配向度であ つても厚み心影響されるため，実用上は厚み補正を行い， 所望の厚みに換算したMOR-cを用いている.MOR-cを用 いれば，厚みが異なる試料でも配向度を比較することが 可能となる，MOR-cは，厚さがゼロではMORは必ず1 となるため，この点と測定した点を直線で結び比例配分 を行うことにより，近似的に式(3)により求められる。

MOR-c $=\left\{t_{c}(M O R-1) / t_{s}\right\}+1$

ここで，tsは試㩽の厚さ、tcは補正したい厚みを表す。
Fiber

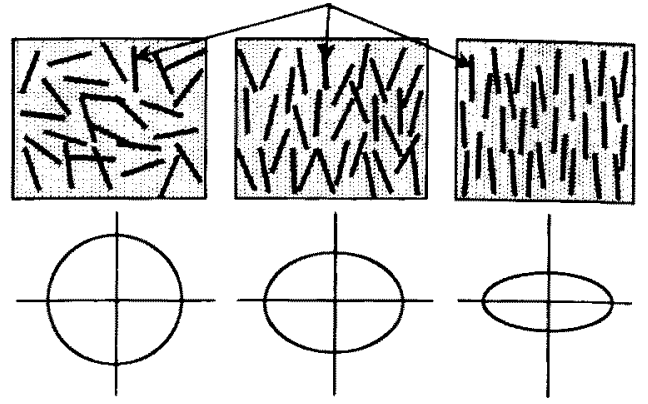

Isotropic

Slightly Anisotropic

Strongly Anisotropic

MOR-c $=1.0 \quad 1.0<$ MOR-c $<1.3$

MOR-c $>1.3$

\section{MOR-c $\fallingdotseq$ Major Axis $/$ Minor Axis}

Fig. 3 The relation between the orientation pattern and the degree of fiber orientation. Orientation degree is expressed in terms of MOR-c, which is calculated as the ratio of major axis to minor axis of orientation pattern.

また，式(1)(2)から複紫誘電率を求める式(4)（5）が導 かれる $(8)$.

$$
\left\{\begin{array}{l}
\varepsilon^{\prime}=1+\frac{\mathrm{A}}{t} \cdot \frac{\omega_{a}-\omega}{\omega_{a}} \\
\varepsilon^{\prime \prime}=\frac{\mathrm{B}}{t}\left(\frac{1}{\mathrm{Q}}-\frac{1}{\mathrm{Q}_{a}}\right)
\end{array}\right.
$$

ここで, $\varepsilon^{\prime}:$ 誘電率, $\varepsilon^{\prime \prime}$ : 誘電損率, $\mathrm{A}$ : 装置定数, $\mathrm{B}$ : 装置定数， $\mathrm{t}$ : 厚み, $\mathrm{Q}$ : 試料挿入時のQ值(共振の鋭さ), $\mathrm{Q}_{a}:$ ブランク時のQ值(共振の鋭さ)を䒺す。

試料を一定の角度だけ回転させる每に共振角周波数心を 测定すれば，試料面方向の誘電率の異方性が測定できる ことになり，その最大力向が裁維の長軸方向を示ナこと になる。

\section{2 ねじれの理論式}

図 4 のように，基準方向Xに対する上層 $(\alpha)$ ，下層 $(\beta)$ の驖維配向角度がそれぞれ $\theta_{1} ， \theta_{2}$ とすると，蓺收縮の力 向と大きさが各層で異なるために，面内カップリンク効 果により起こるせん断Uずみが接着作用によって消え， 面内女ん断応力が働く。このた力，各層には大きさが等 しく方向反对の層間応力 $\tau_{\mathrm{xy}}$ を生しるので、積層板の側面 には一様なトルク

$$
\mathrm{M}_{\mathrm{xy}}=\mathrm{t}^{2} \tau_{\mathrm{xy}}
$$

を受けることになり、权しれが生しる(9).

熱収嬾の大きさの比は，後述するように械維配向度に 閶係し，層間応力は 2 層の配向角度の差の正弦として分 解されるなめ，層間応力が配向度に比例すると仮定する 

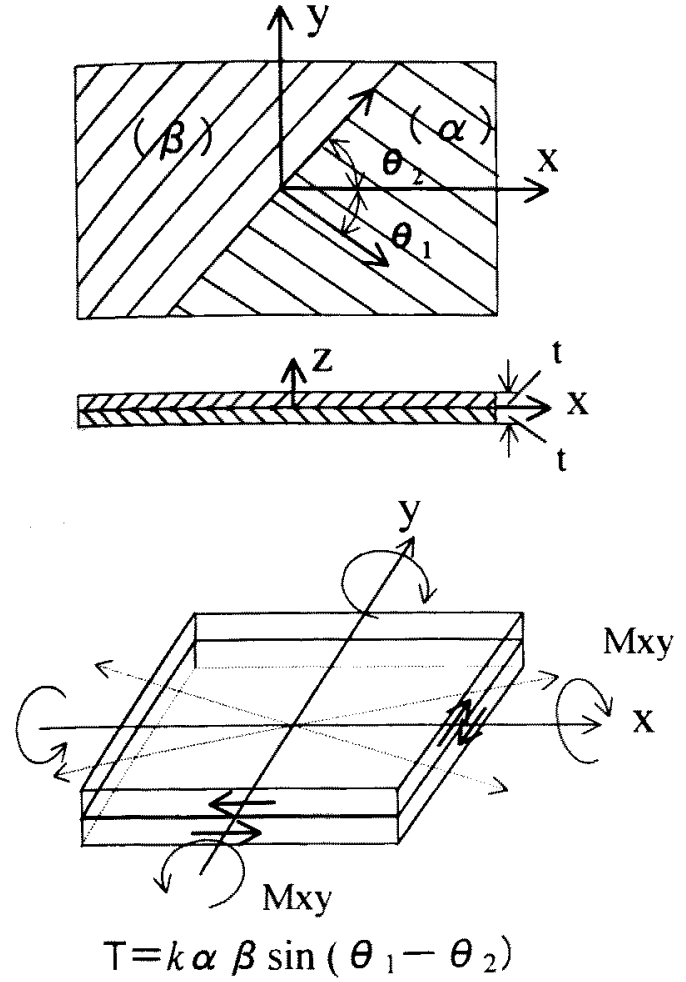

Fig. 4 Twist of two-ply circuit board caused by interlaminar shear stress. $T$ is twist, $\alpha$ and $\beta$ are orientation degrees, $\theta_{1}$ and $\theta_{2}$ are orientation angles and $\mathrm{k}$ is constant.

と、JISのC-5012により測定されるねじれ量Xは(7)式と して表されると考えられる。

$$
\mathrm{X}=k \alpha \beta \sin \left(\theta_{1}-\theta_{2}\right)
$$

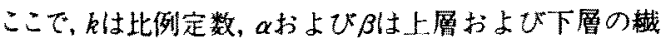

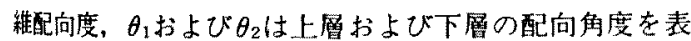
T.

\section{3. 実験}

\section{1 配向度と線脰張係数}

帝人テクノーラを用いた王子製紙製アラミド紙(大きさ

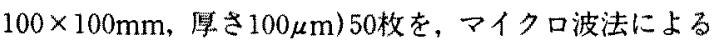
王子計測機器製MOA-2001SA (測定周波数：4.0GHz) 用いて盏維配向を测定し，その中から比較的配向度の差 のある試料を 6 点選んだ。これを瀻維の配向方向（長軸方 向と㭔ぶ)とこれと直角方向(短軸方向と㭔ふ心にそれぞれ

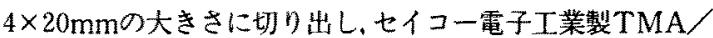
SS150Cにかけて線膨張係数を測定した、図5に示したTMA 温度プロファイルに徒い, 温度幻配 $5^{\circ} \mathrm{C} / \min 50^{\circ} \mathrm{C}$ が $100^{\circ} \mathrm{C}$ における法变化率を温度幅 $50^{\circ} \mathrm{C}$ で除し、線膨張倞

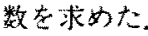

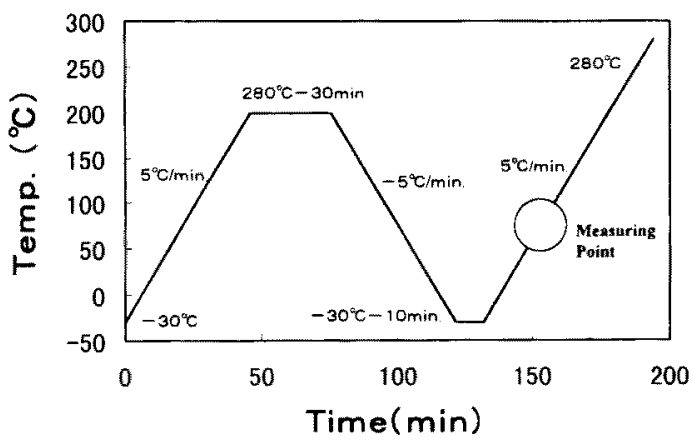

Fig. 5 Change of temperature for thermomechanical analysis to measure the coefficient of linear thermal expansion for prepreg containing aramid fibers.

\section{2 ねじれと織維配向}

樹脂量54.9wt\%(FR 5 相当の㑯熱性工ポキシ樹脂)のプ

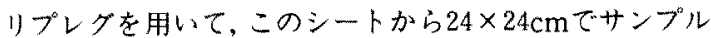

Table 1 Twist for Two Ply Circuit Board

\begin{tabular}{cccccccc}
\hline & & & & \multicolumn{3}{c}{ Twist } \\
\cline { 6 - 8 } Sample & Orientation Degree & & Orientation Angle $\left(^{\circ}\right)$ & \multicolumn{2}{c}{ Calculated } & \multicolumn{2}{c}{ Measured $^{\text {a) }}(1 / \mathrm{mm})$} \\
code & $\alpha$ & $\beta$ & $\theta_{\mathrm{t}}$ & $\theta_{2}$ & $\alpha \beta \sin \left(\theta_{1}-\theta_{2}\right)$ & Before Reflow $^{\text {After Reflow }}$ \\
\hline S1 & 1.05 & 1.057 & 0 & 0 & 0.000 & 0.000292 & 0.000361 \\
S2 & 1.077 & 1.082 & 8 & -9 & 0.341 & 0.000167 & 0.000439 \\
S3 & 1.05 & 1.053 & 17 & -15 & 0.586 & 0.000622 & 0.000922 \\
S4 & 1.149 & 1.157 & 13 & -15 & 0.624 & 0.00045 & 0.000772 \\
S5 & 1.079 & 1.077 & 32 & -28 & 1.006 & 0.001086 & 0.001311 \\
S6 & 1.021 & 1.022 & 38 & -46 & 1.038 & 0.000417 & 0.001061 \\
\hline
\end{tabular}

\footnotetext{
"These values were descrived after being divided by sample area $\left(=3600 \mathrm{~mm}^{2}\right)$.
} 
を切り出し，マイクロ波法により配向を測定した，適当 な配向角およひ配向度のサンプル6点を選び，表 1 に記 載した組み合わせで2ply成形を行い，基板を作成した。成 形は銅箔で2枚のプリプレグを挟み，200 $\mathrm{C}-1$ 時間，圧力 4.9MPaで行った，また，成形後，6×6cmに加工して銅 䇴を塩化鉄水溶液で全面エッ千オフした，最後にこの成 型品を $120^{\circ} \mathrm{C}-30 \mathrm{~min}$. 乾煤し、これを初期サンプルとした。 初期サンプルの机じ量をJIS-C5012(プリント配線板試 験方法)に基づき湘定した。次に温度履歴をかけるために リフロ一処理を $260^{\circ} \mathrm{C}-10 \mathrm{sec} . の$ 条件下で行った。これ 同様の方法でねしれ量を測定した，なお，ねじれ量は基 板面積に比例するため, JISに基づく測定值を試料面穞 3600 $\mathrm{mm}^{2}$ で除した值を採用した。

\section{3 ガラス畿維1軸試料の作成と配向測定}

纎維配向が誘電率の異方性から測定できることを確認

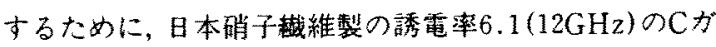
ラス棒状織維(直径 $160 \mu \mathrm{m} \sim 220 \mu \mathrm{m}$ ) 用いて，图 6 のよ うに1軸配向ガラス䋐維の試料を作成した。本数を変え ることにより体積分摔を 0.123 から 0.780 まで変えた 5 点 を,マイクロ波法(測定周波数 $12.5 \mathrm{GHz}$ )により20度毎の 誘電率を測定し、誘電率の複合則に基つくく理諭値と比較 した.

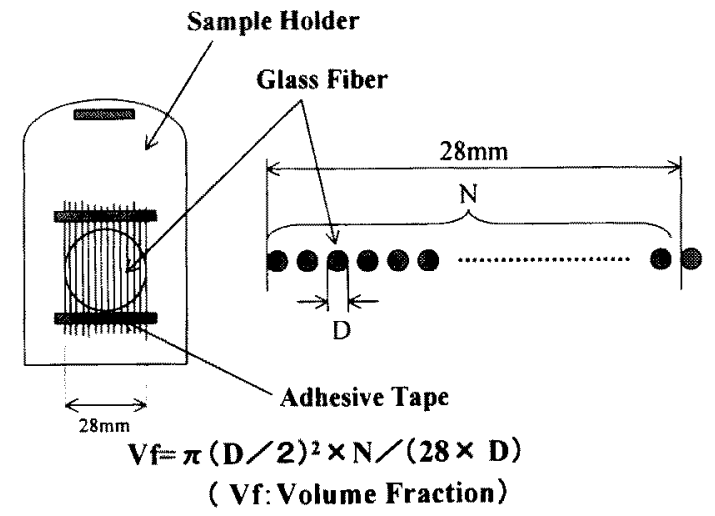

Fig. 6 Uniaxially oriented glass fibers for measurement by microwave method to confirm the dielectric anisotropy changed by the volume fraction.

\section{4. 結果と考察}

\section{1 線膨張係数と㼄維配向}

アラミド紙50点の配向をマイクロ波法で測定し，その 中から比較的配向度の巽なる 6 点について,配向度 (MOR) に対する線膨張係数の变化を图７に示す，裓維の長軸方
向の線膨張係数は $-5 \mathrm{ppm} /{ }^{\circ} \mathrm{C}$ 前後で大きな変化は見られ ないが，短軸方向のそれは配向度が增すにつれて線踾張 係数の䋓対值は小さくなっている，アラミド機維は負の 線膨張係数 $\left(-6 \mathrm{ppm} /{ }^{\circ} \mathrm{C}\right)$ を示寸ため,バインタが含まれ ていることを考虑すると理想的には配向度が大きくなる につれて長軸方向では線膨張係数が負に大きくなり，短 軸方向では負に小さくなると考えられる．今回のデータ ではMORの增加に伴う長軸方向の線膨張保数の下がり方 が小さいが、ほほそれに近い傾向を示している，理想の 形から少し外れているのは，非棠に小さな值を議論して いることによる測定上のばらつき等が考えられ，配向度 の差がさらに大きなもので実験すれば，もう少し傾向が はっきり出るものと思われる。また，長軸方向の線膨張

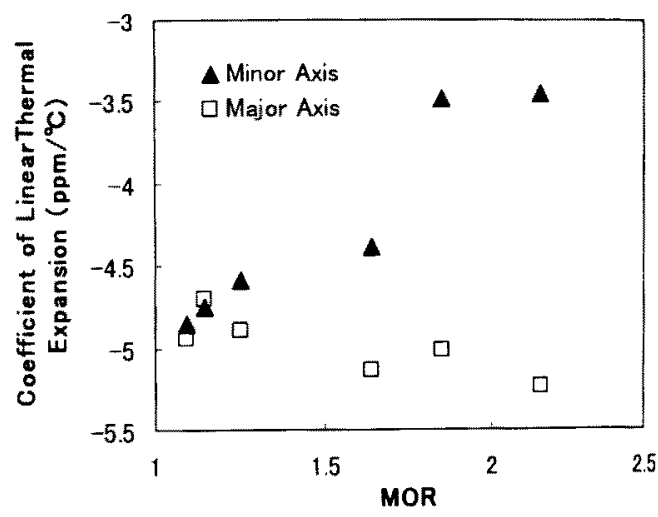

Fig. 7 Coefficient of linear thermal expansion plotted against MOR for prepreg containing aramid fibers.

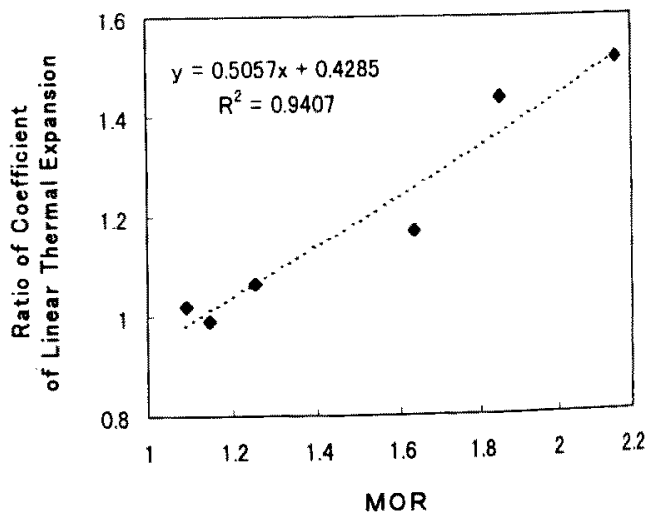

Fig. 8 Ratio of coefficient of linear thermal expansion plotted against MOR for prepreg containing aramid fibers. 
保数と短軸方向のそれとの比と臷維の配向度との関係を 图 8 に示寸.この図からMORが大きいほど線膨張係数比 が大きくなることがわかる，つまり，異方性が大きいほ と収縮淶の縦横比も大きく, MORが収縮比を代用できる ことを示している.

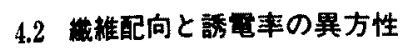

マイクロ波法による配向测定は誘電率の異方性を見て いるが，紙のような械維の集合体においては，嘁維つま りセルロース自体の持つ誘電率の異方性にプラスして、 その形態(並び方)による誘電率の晎方性も検出している ことになる，つまり，ガラスのように誘電的等方性物質 でも，例之ば図 9 のように細長くして平行に列べると， 全体としては誘電率の異方性が出現する[10].この場合, 馀維の長軸方向で誘電率が最大となり，短軸方向で最小 となる、この現象は電磁気学的に説明され，Bilboulの報 告(6)を元に, 二重棈円体を海島構造に置き換えて式を 展開していくと以下の式が導かれる。すなわち，図 9 に 示したように，島に相当する械維を細長い回転棈队体と 仮定し，長軸方向の誘電率を $\varepsilon a$, 短軸方向を $\mathrm{b}$ とすると， それぞれ式(8)(9)のように表される(11]。

$$
\begin{aligned}
& \varepsilon \mathrm{a}=\varepsilon \mathrm{m}[(\varepsilon \mathrm{f}-\varepsilon \mathrm{m})\{\mathrm{Vf}+(1-\mathrm{Vf}) \mathrm{Aa}\}+\varepsilon \mathrm{m}] \\
& /((\varepsilon f-\varepsilon \mathrm{m})(1-V f) A a+\varepsilon m\} \\
& \varepsilon b=\varepsilon m[(\varepsilon f-\varepsilon m)|V f+(1-V f) A b|+\varepsilon m] \\
& /\{(\varepsilon \mathrm{f}-\varepsilon \mathrm{m})(1-\mathrm{Vf}) \mathrm{Ab}+\varepsilon \mathrm{m}\} \\
& \text { ここで, } \mathrm{Aa}=\left\{\left(\mathrm{e}^{2}-1\right) / 2 \mathrm{e}^{2}\right\}[2+(1 / \mathrm{e}) \ln \{(1-\mathrm{e}) \\
& /(1+\mathrm{e})\}] \\
& \mathrm{Ab}=\left(1 / 2 \mathrm{e}^{2}\right)\left[1+\left\{\left(1-\mathrm{e}^{2}\right) / 2 \mathrm{e}\right\} \ln \{(1-\mathrm{e})\right. \\
& /(1+\mathrm{e})\}] \\
& \mathrm{e}=\left(\mathrm{l}-(\mathrm{b} / \mathrm{a})^{2}\right)^{1 / 2}
\end{aligned}
$$

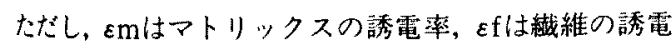
率、Vfは赫維の体積分率, eは棈円の離心率, aは繊維を 掅円体とした場合の長軸の長さ，bは短軸の長さを表す。
上式により、マトリックスおよび䄳維共に誘電的には等 方性であっても，稶維の形状が円でなければ，ての離心 率に対応してマクロ的にみた誘電率に異方性が発現する ことがわかる、栈維のアスペクト比が100程度になってく ると，上式での離心率をを 1 とおいて近似でき，その場合 は式 (8) (9)は, 式(13)(14)のように簡単な形で表される.

$$
\begin{aligned}
\varepsilon \mathrm{a}= & \varepsilon \mathrm{m}(1-\mathrm{Vf})+\varepsilon \mathrm{f} \cdot \mathrm{Vf} \\
\varepsilon \mathrm{b}= & \varepsilon \mathrm{m}\{\varepsilon \mathrm{m}(1-\mathrm{Vf})+\varepsilon \mathrm{f}(1+\mathrm{Vf})\} \\
& /\{\varepsilon \mathrm{m}(1+\mathrm{Vf})+\varepsilon \mathrm{f}(1-\mathrm{Vf})\}
\end{aligned}
$$

この形は、よく知られている弾性率の複合則 [12]と一 致する.

$\varepsilon \mathrm{m} 1.0, \varepsilon \mathrm{f}$ 6.1としてVfを 0 から 1 まで変化ざせた

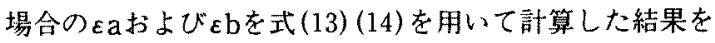

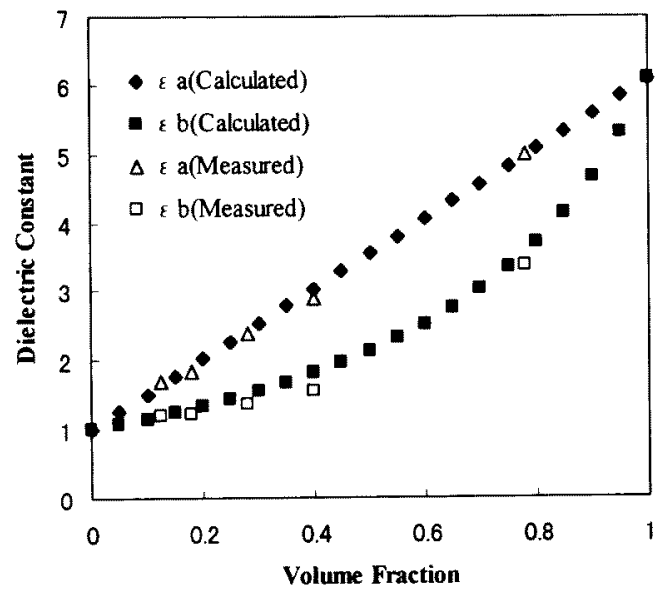

Fig.10 Dielectric constants in the direction of major axis and minor axis of glass fibers plotted against the volume fraction for uniaxially oriented glass fiber sheet. Both calculated values and measured values are plotted.
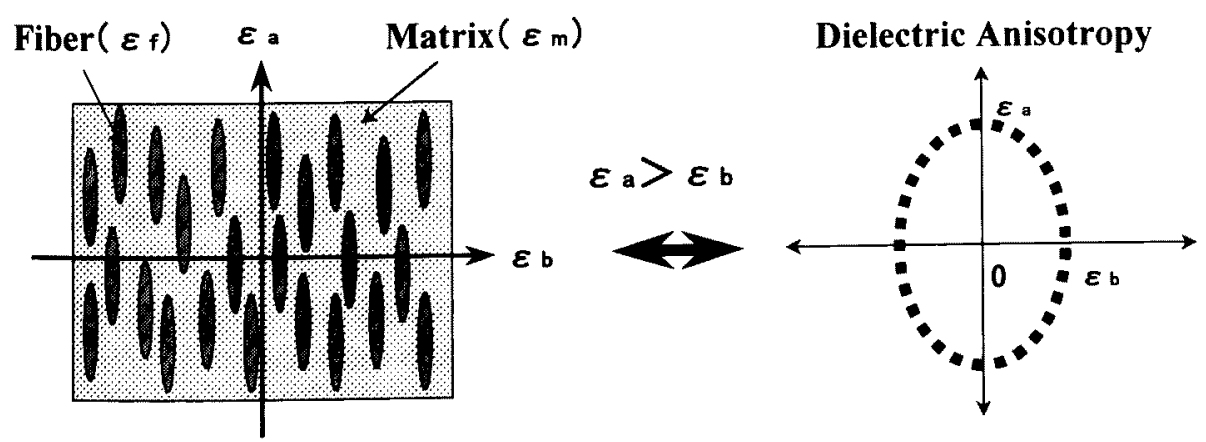

Fig. 9 Composite materials with islands-sea structure present macroscopic anisotropy of dielectric constant because of the shape of islands, even if the islands and sea are dielectrically isotropic themselves. 
图10に示す。また，配向度を表す $\Delta \varepsilon^{\prime}(=\varepsilon a-\varepsilon b) と V f と$ の関係を図11に示す，この場合は，体積分率が $65.3 \% の$ 時に異方性が最大 $\left(\Delta \varepsilon^{\prime}=1.563\right)$ となることがわかる.

この確認のために，体積分率の異なるがラス械維 1 朝 配向試料 5 点について, マイクロ波法で長軸方向の誘電 率 $\varepsilon \mathrm{a}$ と短軸方向の誘電率 $\varepsilon \mathrm{b}$ を測定した. その結果を表 2 に示す。またこの 5 点の測定結果を図10および図11に “Measured”として迫加プロットした。ほほ理論カーブ に載っており，紻維が等方性であってもその亚び方で誘 電的異方性が現れることが，マイクロ波法によって確認

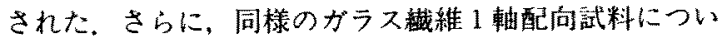
て, 誘電率の方位角方向分布を, 理論值と寒測值につい て比較を行った結果, 両者は良く一致した。試料“nag5” について，両者の比較結果を図12に示寸，理論值につい

Table 2 Dielectric Constant Measured by Microwave Method for Uniaxially Oriented Glass Fiber Sheet

\begin{tabular}{ccccccc}
\hline $\begin{array}{c}\text { Sample } \\
\text { code }\end{array}$ & Number $^{\mathrm{a})}$ & $(\mathrm{mm})$ & Vf & $\varepsilon \mathrm{a}^{\text {b) }}$ & $\varepsilon \mathrm{b}^{\mathrm{c})}$ & $\varepsilon \mathrm{a}-\varepsilon \mathrm{b}$ \\
\hline nag1 & 22 & 0.20 & 0.123 & 1.697 & 1.188 & 0.510 \\
nag2 & 32 & 0.20 & 0.180 & 1.828 & 1.218 & 0.610 \\
nag3 & 50 & 0.20 & 0.281 & 2.383 & 1.370 & 1.013 \\
nag4 & 79 & 0.18 & 0.399 & 2.901 & 1.556 & 1.345 \\
nag5 & 139 & 0.20 & 0.780 & 5.004 & 3.371 & 1.633 \\
\hline
\end{tabular}

a) Number of Fibers in $28 \mathrm{~mm}$ Length.

bielectric Constant in the Direction of Major Axis.

'Dielectric Constant in the Direction of Minor Axis.

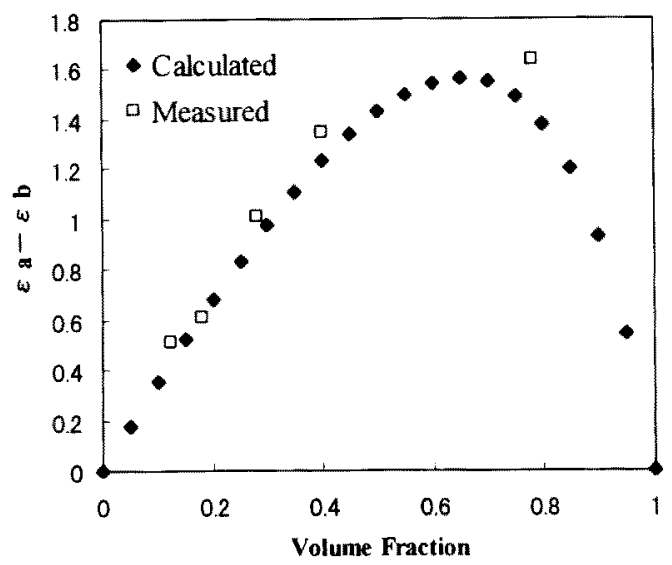

Fig.11 Dielectric anisotropy $\left(=\Delta \varepsilon^{\prime}\right)$ plotted against the volume fraction for uniaxially oriented glass fiber sheet. Both calculated values and measured values are plotted.

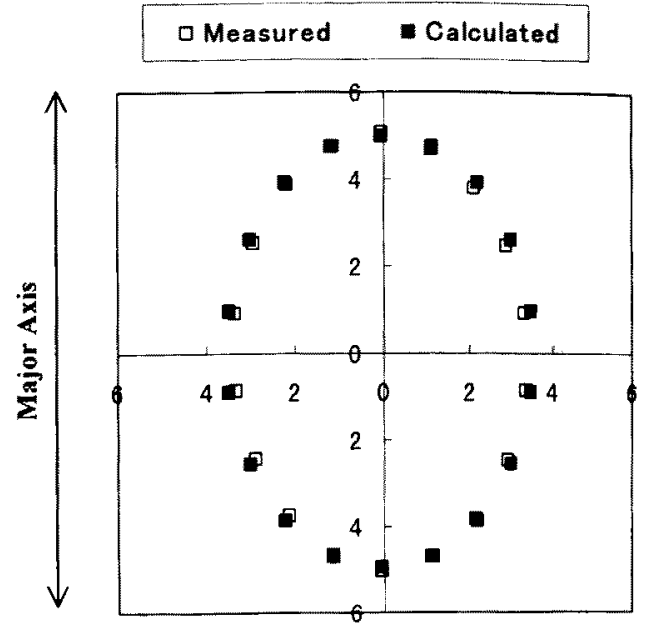

Fig.12 Comparison between calculated value and measured value for angular dependence of dielectric constant of uniaxially oriented glass fiber sheet "nag5".

ては， $\varepsilon a=4.978, \varepsilon b=3.548 を$ 用いて誘䉓率棈円体として 計算した，実測値については，マイクロ波法による20度 每の湘定值を用いな、これにより、誘電率の異方性を既 定することにより，幽維配向の評価ができることか確認 された，つまり、誘電率の最大方向が平均的な峨維配向 主軸方向であり、, $\Delta \varepsilon^{\prime}$ あるいはMOR-cでその配向度が評洒 できることがわかったまま，樴維配向度を比較する場 合，㰇維の体積分率を同一にする必要があることも確認 された.

なお、このような形状に基づく異方性が発現するかど うかは瀻維のサイズや測定部分の面積にも関連するが、 今回のアラミド臷維の場合は直径 $12 \mu \mathrm{m}$, 長さ $3 \mathrm{~mm}$, それ に対して測定面積は67mm (12GHzの場合)となっており，どちらの周波数帯で測定 しても，十分にマクロ的な異方性の発現が測定できる大 きさであった。

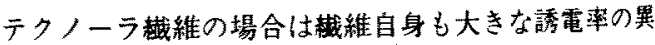
方性がある(長軸方向が最大になる)ので、全体としての 誘電率の異方性は同条件のガラス栈維に比へてさらに大 きくなることは容易に推定できるが、理論的・定量的な 解析については今後さらに検討して行きたい。

\section{3 ねじれと織䧴配向}

樹脂を含浸させたプリプレグ貼り合わせ基板の权しれ の原因としては，次の3 点が考之られる、第 1 に，成形

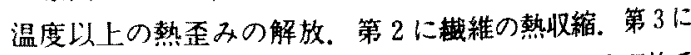
含浸樹脂の硬化収縮．その内でも第 3 の原因が支配的で あり，合浸樹脂の硬化収縮が载維配向により暴方性をも 
つことによると考えられる。これを塞付けるデータとし て, $200^{\circ} \mathrm{C}$ 成型品㧍よび $230^{\circ} \mathrm{C}$ 成型品のTMAを $260^{\circ} \mathrm{C}$ まで の条件で測定したところ, $200^{\circ} \mathrm{C}$ 品において不可逆な収縮 が大きくなるという結果を得た，一方，230 $\mathrm{C}$ 品では，そ の収縮は $200^{\circ} \mathrm{C}$ 品に比へ，かなり小さいさいことも確認し た。つまり，200品と $230^{\circ} \mathrm{C}$ 品の収縮量の差が大きいこ とから, $200^{\circ} \mathrm{C}$ 成形では樹脂の完全硬化まで至っておらず， リフローを通すことにより硬化が進むと考えられる。 そ の次に来る要因として、械維の収縮等があると考えられ ๖.

マイクロ波方式で測定した配向度と配向角度を用いて， 式(7)により計算したねじれ量とJISに基づく赛測值を表 1に示す。また，計算值と実測值との関係を図13に示す。 リフロー前の相関係数は0.641であるが、リフロー後のそ れは0.935であり，強い相関があることがわかった。この 赫果から，樹脂を含浸させたプリプレグ貼り合わせ基板 のれしれは，繊維の配向度と配向角度に大きく依存し， 式(7)によりその大きさが推定できることが分かった。逆 に、攼れれ小さくするには，配向度をできるだけ小さ 〈するか，または両層の配向角度をできるだけ同一にし て貼り合わせることが必要であることが確認できた。

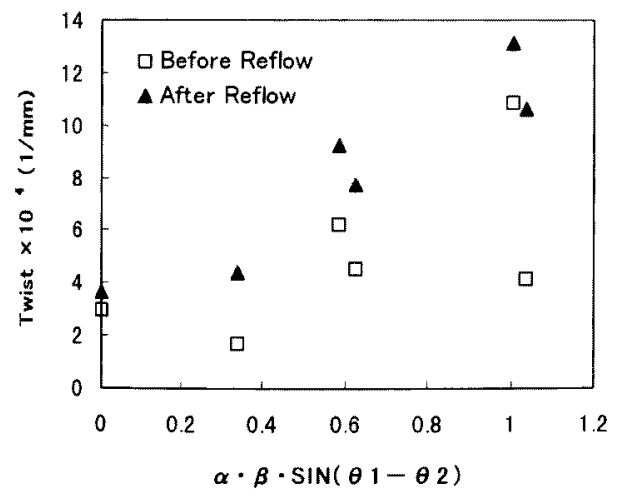

Fig.13 Measured value vs. calculated value for the twist of two-ply circuit board. The former was obtained by dividing the measured value according to JIS by sample area $\left(=3600 \mathrm{~mm}^{2}\right)$. The latter is calculated by proposed equation.

\section{5. 結言}

(1)载維が等方性であっても，その並び方により全体と して誘電率の異方性が発現する現象を表す理論式と, 、 イクロ波法による誘電率の湘定結果が一致することをガ ラス㧴維 1 軸配向シートを作成して確認した。この結果 より, 誘電事の異方性を見ているマイクロ波法は, 㵶維
配向を評価するのに有効な方法であることか確認された。 つまり, 誘電率の最大方向が平均的に見た繊維配向方向 であり，賦維の体積分率が同一であるならば, $\Delta \varepsilon^{\prime}\left(=\varepsilon_{\text {max }}^{\prime}-\right.$ $\varepsilon_{\min }^{\prime}$ )るいはMOR-cで䋐維配向度が評価できる。

(2)アラミド紙を用いたプリプレグの線膨張係数の長軸 方向と短軸方向の比と、マイクロ波法による繊維配向度 を表すMORには強い相関関係があり，熱収縮比はMOR で推定できることがわかった。

(3) 2 層貼り合わせ楀層回路基板の熱によるねしれは, 繊維配向に支配された熱収縮率の異方性が各層で異なる ために生じる層間応力によって発生することから，雨層 の配向度 (MOR) と配向角度の関数としてねじれ量を表わ す式を提案し、この式を用いて計算した結果とJISに基つ く実測値との間には強い相関関倸があることがわかった。 逆に、るじれのない積層基板を作るためには，配向度を できるだけ小さくするか，または両層の配向角度をでき るだけ同一にして貼り合わせることが必要であることが 分かった。

\section{謝辞}

本研究を行うにあたりガラス截維を提供していただい た日本硝子繊維踭開発部の佐藤典明氏に深謝申し上げる.

\section{参考文献}

1. 平川 櫓, 「電子材料」, 工業調查会, $28[10], \mathrm{p} .61$ (1989).

2. J. K. Craver and D. L. Taylor, Tappi, 48[3], 142 (1965).

3. 加藤靖典, 栗山富夫, 永田 誠(山陽国策パルプ), 特開昭61-142464.

4. 和田英樹、「赛用プラスチック成形加工事典」, 産業 調査会, p.379(1997).

5 . 大崎茂芳, 永田紳一, 酒井清和, 藤井良彦, 電子通 信学会(MW84-66), p.7(1984).

6. R. R. Bilboul, Brit. J. Appl. Phys. (J. Phys. D). Ser. 2. 2. 921 (1969).

7. 藤澤和男, 岡本尚道,「マイクロ波回路例題演習」, コロナ社, p.157 (1975).

8. S. Osaki, J. Appl. Polym. Sci., 37, 527 (1989).

9. 赤坂 隆, 「複合材料工学」, 林毅編, 日科技連出 版社, p. 540(1971).

10. 安部康明, 第41回日本学術会議材料研究連合講演会 予稿集，p.353(1997)，お゙よび，材料，印刷中.

11. 水田紳一, 小山清人, 峨維学会予稿集, 1997, F-112. 12. D. 八ル著, 宮入裕夫, 池上晧三, 金原勲共訳, 「複合 材料入門」，培風館，p.74(1984)。 